\title{
BREEDING JAMINAN FIDUSIA: POTENSI DALAM MENDORONG EKONOMI NEGARA
}

\author{
Dyah Hapsari Prananingrum \\ Staf Pengajar Fakultas Hukum Universitas Kristen Satya Wacana \\ Korespondensi: dyah.prananingrum@yahoo.com
}

\begin{abstract}
Abstrak
Breeding atau pemuliaan diartikan sebagai perihal membuat (menjadikan) sesuatu hal lebih bermutu atau lebih unggul. Dengan demikian pemuliaan fidusia adalah upaya menjadikan fidusia lebih unggul untuk dapat digunakan sebagai jaminan kredit. Hukum dapat berperan dalam pembangunan ekonomi karena hokum mampu menciptakan stability, predictability dan fairness. Seturut dengan upaya mendorong ekonomi nasional melalui kegiatan usaha, lembaga jaminan khususnya jaminan fidusia menjadi unggulan untuk menggerakkan laju perekonomian. Potensi cukup besar dan belum digarap dengan maksimal adalah penggunaan lembaga jaminan fidusia pada pelaku usaha UMKM.
\end{abstract}

Kata-kata Kunci: Pemuliaan; Fidusia; UMKM.

\begin{abstract}
Breeding is defined as making something in such a way so that it possesses higher quality or superiority. Thus fiduciary breeding is an effort to make the fiduciary superior to be utilized as loan collateral. Law could play a role in the economic law development. The relevant issue here is whether the law is able to create stability, predictability and fairness for businesses. In accordance with the efforts to boost the national economy through business activities, fiduciary is a primary scheme to boost up the economy. Considerable potential that has not been better exploited is the use of fiduciary institution among SME business operators.
\end{abstract}

Key Words: Breeding; Fiduciary; SME. 


\section{PENDAHULUAN}

Kondisi ekonomi global saat ini tidak cukup baik untuk mendorong pertumbuhan ekonomi nasional, disebabkan pemulihan dari krisis ekonomi tidak secepat yang diharapkan. Lemahnya harga-harga komoditas dunia yang disebabnya berkurangnya permintaan serta kondisi pasar uang yang tidak menggembirakan, sangat mempengaruhi Indonesia sebagai negara berkembang. Pergeseran modal asing keluar dari Indonesia serta tidak cukup besarnya modal asing yang masuk tidak cukup mampu mendorong pertumbuhan ekonomi.

Dalam kegiatan perekonomian yang sebenarnya, pertumbuhan ekonomi menunjukkan peningkatan secara fisik terhadap produksi barang dan jasa yang berlaku di suatu negara. Peningkatan ini dapat dilihat antara lain dari bertambahnya produksi barang industri yang dihasilkan perusahaan, berkembangnya infrastruktur, bertambahnya produksi barang modal dan bertambahnya sektor jasa.

Dalam konteks pertumbuhan ekonomi yang demikian maka modal memiliki arti sangat penting bagi kegiatan-kegiatan ekonomi tersebut. Karena bagi perusahaan modal merupakan satu bagian yang penting baik pada awal kegiatan usahanya maupun untuk pengembangan usaha lebih lanjut. Modal atau kapital sering diartikan sebagai kekayaan total dari usaha ekonomi, kekayaan usaha yang segera dapat diubah ke dalam bentuk tunai, bagian pokok dari pinjaman sebagaimana yang dibedakan dari bunga, bahkan sering diartikan sejumlah uang saja adalah faktor yang mutlak penting perlu ada dalam setiap perusahaan. ${ }^{1}$

Sejalan dengan perkembangan teknologi dan makin jauhnya spesialisasi dalam bidang produksi perusahaan baik dalam bentuk produksi barang ataupun jasa, serta makin banyaknya perusahaan-perusahaan yang terus bertumbuh, maka modal mempunyai arti sebagai faktor produksi utama dari kegiatan-kegiatan usaha ini. Modal diperoleh dari beberapa sumber yang dapat dibagi menjadi 2 (dua) bagian besar yaitu sumber internal yang berasal dari dalam perusahaan atau pelaku usaha sendiri, dan sumber modal eksternal yang berasal dari dunia perbankan, lembaga pembiayaan dalam wujud hutang piutang (kredit) ataupun sumber eksternal lainnya yang lain.

Salah satu produk yang diberikan oleh bank dalam membantu kelancaran usaha debiturnya adalah pemberian kredit di mana hal ini merupakan salah satu fungsi bank yang sangat mendukung pertumbuhan ekonomi. Pengertian kredit menurut Pasal 1 angka 2 Undang-Undang Nomor 10 Tahun 1998 tentang Perubahan atas UndangUndang Nomor 7 Tahun 1992 tentang Perbankan (UU Perbankan) adalah

Nindyo Pramono, Sertifikasi saham PT Go Public dan Hukum Pasar Modal di Indonesia (disertasi, Universitas Gadjah Mada 1997) 54. 
sebagai berikut: "Kredit adalah penyediaan uang atau tagihan yang dapat dipersamakan dengan itu, berdasarkan persetujuan atau kesepakatan pinjam meminjam antara Bank dengan pihak lain yang mewajibkan pihak peminjam untuk melunasi hutangnya setelah jangka waktu tertentu dengan jumlah bunga." Pemberian kredit yang dilakukan oleh bank sebagai suatu lembaga keuangan, sudah semestinya harus dapat memberikan perlindungan hukum bagi pemberi dan penerima kredit serta pihak yang terkait mendapat perlindungan melalui suatu lembaga jaminan hukum bagi semua pihak yang berkepentingan. Dalam Pasal 1131 Kitab UndangUndang Hukum Perdata (KUH Perdata) terdapat ketentuan tentang jaminan yang sifatnya umum, artinya berlaku terhadap setiap debitor dan kreditor dan berlaku demi hukum tanpa harus diperjanjikan sebelumnya, yang menyatakan bahwa: "Segala kebendaan si berutang, baik yang bergerak maupun yang tak bergerak, baik yang sudah ada maupun yang akan ada dikemudian hari, menjadi tanggungan untuk segala perikatannya perseorangan." Selanjutnya Pasal 1132 KUH Perdata menegaskan: "Kebendaan tersebut menjadi jaminan bersama-sama bagi semua orang yang mengutangkan padanya, pendapatan penjualan bendabenda itu dibagi-bagi menurut keseimbangan, yaitu menurut besar kecilnya piutang masing-masing, kecuali apabila diantara para kreditor itu ada alasan-alasan yang sah untuk didahulukan.”
Pada masa permulaan KUH Perdata, lembaga jaminan gadai dan hipotek, dirasa sudah cukup untuk mencakup seluruh kebutuhan akan praktik penjaminan dalam lalu lintas hutangpiutang (kredit). Gadai merupakan suatu hak yang diperoleh kreditur atas suatu benda bergerak yang diberikan debitur kepadanya (inbezitstellingen) sebagai jaminan pelunasan pembayaran dan memberikan hak kepada kreditur untuk mendapat pembayaran lebih dahulu dari kreditur-kreditur lainnya atas hasil penjualan benda tersebut (Pasal 1150 KUH Perdata). Gadai mendapat pengaturan secara khusus dalam Pasal 1150-1160 KUH Perdata. Pasal 1150 KUH Perdata menjelaskan bahwa gadai adalah suatu hak yang diperoleh kreditur atas suatu barang bergerak, yang diserahkan kepadanya oleh kreditur, atau oleh kuasanya, sebagai jaminan atas utangnya, dan yang memberi wewenang kepada kreditur untuk mengambil pelunasan piutangnya dan barang itu dengan mendahalui kreditur-kreditur lain; dengan pengecualian biaya penjualan sebagai pelaksanaan putusan atas tuntutan mengenai pemilikan atau penguasaan, dan biaya penyelamatan barang itu, yang dikeluarkan setelah barang itu sebagai gadai dan yang harus didahulukan.

Dengan demikian gadai diperoleh oleh seorang berpiutang (kreditur) atas suatu benda bergerak yang diserahkan oleh seorang yang berhutang (debitur) atau oleh orang lain atas namanya, yang memberikan kekuasaan kepada kreditur untuk mengambil pelunasan hutang 
dari benda yang menjadi jaminan tersebut. Pelunasan hutang yang ditumpukan pada benda yang diserahkan sebagai jaminan tersebut (benda gadai), mendudukkan kreditur lebih didahulukan dari kreditur-kreditur lainnya. Namun demikian, kedudukan kreditur yang preference tersebut dikecualikan khusus untuk biaya-biaya yang dikeluarkan untuk melelang benda tersebut dan biaya yang telah dikeluarkan untuk menyelamatkan benda tersebut maupun pajak, merupakan biaya-biaya yang harus didahulukan. Hak gadai diadakan guna mencegah debitur mengubah benda yang dijaminkan sehingga akan merugikan bagi pihak yang menjadi pemegang gadai.

Sedangkan hipotek adalah suatu hak kebendaan atas barang tak bergerak yang dijadikan jaminan dalam pelunasan suatu perikatan (Pasal 1162 KUH Perdata). Hipotek diatur secara khusus dalam Pasal 1162-1232 KUH Perdata. Di dalam perjanjian kredit akta hipotek merupakan suatu grosse akta yang telah mempunyai titel eksekutorial yaitu akta yang sama dengan kekuatan hukum tetap. Hipotek hanya dapat diletakkan atas benda yang sudah ada.

Dalam sejarah hipotek, lembaga hipotek diberlakukan sebagai jaminan yang melekat pada seluruh benda tidak bergerak, tetapi dalam perkembangannya jaminan atas tanah sebagai salah satu benda tidak bergerak telah diatur dalam lembaga sendiri yaitu hak tanggungan. Pada hak tanggungan ada beberapa asas yang dapat digunakan untuk membedakan hak tanggungan dari jenis dan bentuk jaminan utang yang lain. Asas jaminan jaminan tersebut yaitu hak tanggungan memberikan kedudukan yang diutamakan bagi kreditur pemegang hak tanggungan; hak tanggungan tidak dapat dibagi-bagi; hak tanggungan hanya dapat dibedakan pada hak atas tanah yang telah ada; hak tanggungan dapat dibebankan selain atas tanahnya juga berikut benda-benda yang berkaitan dengan tanah tersebut; hak tanggungan dapat dibebankan juga atas benda-benda yang berkaitan dengan tanah yang baru akan ada di kemudian hari; hak tanggungan dapat dijadikan jaminan untuk utang yang baru akan ada; hak tanggungan dapat menjamin lebih dari satu utang; dan hak tanggungan wajib didaftarkan. Asas yang menyatakan bahwa hak tanggungan dapat dijadikan jaminan untuk utang yang baru akan ada, dilarang dalam hipotek yang tidak memperbolehkan menjaminkan benda yang belum ada. Hipotek atas bendabenda yang baru akan ada di kemudian hari adalah batal, sebagaimana diatur dalam Pasal 1175 KUH Perdata.

Tiga jaminan tersebut (yaitu gadai, hipotek dan tanggungan) didasarkan pada perjanjian bernama yang bersifat accesoir. Selanjutnya bahwa jaminan kebendaan di atas merupakan jaminan yang mempunyai hubungan langsung dengan bendanya, yang atas bendabenda jaminan tersebut kreditur mempunyai hak kebendaan atau zackelijkrecht, dengan cirri: mengikuti kemanapun benda berada atau droit de suit atau zaakgevolg; dapat beralih atau dialihkan; diprioritaskan atau asas 
prioriteit; separatis dalam hal terjadi kepailitan dan dapat dipertahanankan dari pihak lain.

Seiring dengan perkembangan kebutuhan akan permodalan sebagai implikasi dari perkembangan bisnis dan perdagangan, maka lembaga jaminan dalam bentuk gadai dan hipotek dirasa tidak memadai lagi. Pada jaminan gadai, benda gadai harus dikeluarkan dari kekuasaan si pemberi gadai dan selanjutnya dipegang oleh kreditur pemegang gadai (vuistpand) atau pihak ketiga pemegang gadai. ${ }^{2}$ Pada benda yang menjadi jaminan adalah benda produksi dan transportasi maka jaminan gadai tidak dapat diletakkan. Lembaga fidusia dipilih guna mengatasi kelemahan dari gadai tersebut. Pengertian fidusia adalah pengalihan hak kepemilikan suatu benda atas dasar kepercayaan dengan ketentuan bahwa benda yang hak kepemilikannya dialihkan tetap dalam penguasaan pemilik benda. ${ }^{3}$

Dalam Undang-Undang Nomor 42 Tahun 1999 tentang Jaminan Fidusia (UU Fidusia), disebutkan bahwa jaminan fidusia adalah hak jaminan atas benda bergerak baik yang berwujud maupun yang tidak berwujud dan benda tidak bergerak khususnya bangunan yang tidak dapat dibebani hak tanggungan sebagaimana dimaksud dalam UndangUndang Nomor 4 Tahun 1996 tentang Hak Tanggungan Atas Tanah Beserta Benda-Benda Yang Berkaitan dengan Tanah (UUHT) yang tetap berada dalam penguasaan pemberi fidusia, sebagai agunan bagi pelunasan utang tertentu, yang memberikan kedudukan yang diutamakan kepada penerima fidusia terhadap kreditor lainnya. ${ }^{4}$

Breeding atau pemuliaan diartikan sebagai "perihal membuat (menjadikan) sesuatu hal lebih bermutu atau lebih unggul." Dengan demikian pemuliaan atau breeding fidusia adalah suatu upaya menjadikan fidusia lebih unggul untuk dapat digunakan sebagai jaminan kredit. Dalam kondisi ini, hukum dapat berperan dalam pembangunan ekonomi karena hukum mampu menciptakan stability, predictability dan fairness. Stability adalah potensi hukum untuk menyeimbangkan dan mengakomodasi kepentingan-kepentingan yang saling bersaing. Predictability adalah kebutuhan hukum untuk meramalkan akibat dari langkah-langkah yang diambil. Adapun aspek keadilan adalah untuk menjaga mekanisme yang sehat dan mencegah birokrasi yang berlebih. ${ }^{5}$

J. Satrio, Hukum Jaminan dan Hak Jaminan Kebendaan Fidusia (PT. Citra Aditya Bakti 2002) 9. Fidusia menurut asal katanya berasal dari bahasa Romawi fides yang berarti kepercayaan. Fidusia merupakan istilah yang sudah lama dikenal dalam bahasa Indonesia. Begitu pula istilah ini digunakan dalam Undang-Undang No. 42 Tahun 1999. Dalam terminologi Belanda istilah ini sering disebut secara lengkap yaitu Fiduciare Eigendom Overdracht (F.E.O.) yaitu penyerahan hak milik secara kepercayaan. Sedangkan dalam istilah bahasa Inggris disebut Fiduciary Transfer of Ownership.

4 Pasal 1 UU Fidusia.

$5 \quad$ Erman Rajagukguk, 'Hukum Ekonomi Indonesia Memperkuat Persatuan Nasional, Mendorong dan Memperluas Kesejahteraan Sosial' (Seminar Pembangunan Hukum Nasional VII, Bali, 2003). 


\section{PEMBAHASAN}

\section{Potensi Penggunaan Lembaga Fidusia}

Seturut dengan upaya mendorong ekonomi nasional melalui kegiatan usaha, lembaga jaminan khususnya jaminan fidusia menjadi unggulan untuk menggerakkan laju perekonomian. Potensi yang cukup besar dan yang belum digarap dengan maksimal adalah penggunaan lembaga jaminan fidusia pada pelaku usaha UMKM.

Apakah UMKM? Usaha Mikro adalah usaha produktif milik orang perorangan dan/atau badan usaha perorangan yang memenuhi kriteria usaha mikro sebagaimana diatur dalam UndangUndang Nomor 20 Tahun 2008 tentang Usaha Mikro, Kecil dan Menengah (UU UMKM). Merujuk pada definisi yang terdapat dalam UU UMKM, usaha kecil adalah usaha ekonomi produktif yang berdiri sendiri, yang dilakukan oleh orang perorangan atau badan usaha yang bukan merupakan anak perusahaan atau bukan cabang perusahaan yang dimiliki, dikuasai, atau menjadi bagian baik langsung maupun tidak langsung dari usaha menengah atau usaha besar yang memenuhi kriteria usaha kecil sebagaimana diatur dalam undang-undang.

Sedangkan definisi usaha menengah adalah usaha ekonomi produktif yang berdiri sendiri, yang dilakukan oleh orang perseorangan atau badan usaha yang bukan merupakan anak perusahaan atau cabang perusahaan yang dimiliki, dikuasai, atau menjadi bagian baik langsung maupun tidak langsung dengan usaha kecil atau usaha besar dengan jumlah kekayaan bersih atau hasil penjualan tahunan sebagaimana diatur dalam undangundang.

Batasan UMKM sebagaimana disebutkan dalam UU UMKM diatur menurut aset dan omset sebagai berikut

1. Usaha Mikro adalah usaha produktif milik perorangan dan/atau badan usaha perorangan yang memenuhi kriteria sebagai berikut:

a) memiliki kekayaan bersih paling banyak Rp 50.000.000,00 (lima puluh juta rupiah) tidak termasuk tanah dan bangunan tempat usaha; atau

b) memiliki hasil usaha hasil penjualan tahunan paling banyak $\mathrm{Rp}$ 300.000.000,00 (tiga ratus juta rupiah).

2. Usaha Kecil adalah usaha ekonomi produktif yang berdiri sendiri, yang dilakukan oleh orang perorangan atau badan usaha yang bukan merupakan anak perusahaan atau bukan cabang perusahaan yang memiliki, dikuasai atau menjadi bagian baik langsung maupun tidak langsung dari usaha menengah atau usaha besar yang memenuhi kriteria sebagai berikut:

a) memiliki kekayaan bersih lebih dari Rp 50.000.000,00 (lima puluh juta rupiah) sampai dengan paling banyak Rp 500.000.000,00 (lima ratus juta rupiah) tidak termasuk tanah dan bangunan tempat usaha; atau 
b) memiliki hasil penjualan tahunan lebih dari Rp 300.000.000,00 (tiga ratus juta rupiah) sampai dengan paling banyak Rp 2.500.000.000,00 (dua miliar lima ratus juta rupiah).

3. Usaha Menengah adalah usaha ekonomi produktif yang berdiri sendiri, yang dilakukan oleh orang perseorangan atau badan usaha yang bukan merupakan anak perusahaan atau cabang perusahaan yang dimiliki, dikuasai atau menjadi bagian baik langsung maupun tidak langsung dengan Usaha Kecil atau Usaha Besar dengan jumlah kekayaan bersih atau hasil penjualan tahunan, sebagai berikut:

a) memiliki kekayaan bersih lebih dari Rp 500.000.000,00 (lima ratus juta rupiah) sampai dengan paling banyak Rp 10.000.000.000,00 (sepuluh miliar rupiah) tidak termasuk tanah dan bangunan tempat usaha; atau

b) memiliki hasil penjualan tahunan lebih dari Rp 2.500.000.000,00 (dua miliar lima ratus juta rupiah) sampai dengan paling banyak $\mathrm{Rp}$ 50.000.000.000,00 (lima puluh miliar rupiah).

Badan Pusat Statistik (BPS) memberikan definisi UKM berdasarkan kuantitas tenaga kerja. Usaha mikro mempekerjakan tenaga kerja maksimal 4 orang. Usaha kecil merupakan usaha yang memiliki jumlah tenaga kerja 5 sampai dengan 19 orang. Sedangkan usaha menengah merupakan entitas usaha yang memiliki tenaga kerja 20 sampai dengan 99 orang, dan di atas 100 orang masuk dalam kelompok Usaha Besar.

Data statistik menunjukkan jumlah unit usaha kecil mikro dan menengah (UMKM) mendekati 99,98\% terhadap total unit usaha di Indonesia. Sementara jumlah tenaga kerja yang terlibat mencapai 91,8 juta orang atau 97,3\% terhadap seluruh tenaga kerja Indonesia. Menurut Syarif Hasan, mantan Menteri Koperasi dan UKM seperti dilansir sebuah media massa, bila dua tahun lalu jumlah UMKM berkisar 52,8 juta unit usaha, maka pada 2011 sudah bertambah menjadi 55,2 juta unit. Setiap UMKM rata-rata menyerap 3-5 tenaga kerja. Dengan adanya penambahan sekitar 3 juta unit maka tenaga kerja yang terserap bertambah 15 juta orang. Pengangguran diharapkan menurun dari 6,8\% menjadi $5 \%$ dengan pertumbuhan UMKM tersebut. Hal ini mencerminkan peran serta UMKM terhadap laju pertumbuhan ekonomi memiliki signifikansi cukup tinggi bagi pemerataan ekonomi Indonesia karena memang berperan banyak pada sektor riil. ${ }^{6}$

Berdasarkan data di atas, maka dapat dilihat bahwa usaha kecil, mikro dan menengah merupakan potensi bagi penggunaan jaminan fidusia, terlebih dapat diketahui bahwa kendala terbesar dari UMKM adalah masalah pendanaan dimana pelaku usaha UMKM ini tidak

$6 \quad$ Aries Musnandar, 'Peran UKM dalam Pertumbuhan Ekonomi Bangsa' (2014) <http:// www.umm.ac.id/id/detail-321-peran-ukm-dalam-pertumbuhan-ekonomi-bangsa-opiniumm.html> diakses 12 Maret 2015. 
mampu mengakses dana perbankan karena tidak adanya jaminan (khususnya untuk jaminan gadai dan hipotek). Karena benda yang dapat mereka jaminkan lebih merupakan benda produksi dan transportasi. Di mana benda jaminan tersebut masih sangat dibutuhkan dalam proses produksi.

Sebenarnya kebutuhan dana pada UMKM tersebut dapat dipenuhi melalui pola pembiayaan UMKM yang berasal dari perbankan maupun lembaga keuangan bukan bank. Manakala diklasifikasikan pola dan jenis pembiayaan dari berbagai sumber tersebut, maka terdapat 4 pola, yaitu:

1. Pembiayaan Perbankan pemerintah dan swasta

Yaitu pembiayaan bagi pelaku UMKM melalui bank-bank pemerintah maupun swasta dengan tetap menggunakan peraturan perbankan yang berlaku.

2. Program Lembaga Pengelolaan Dana

Bergulir (LPDB) Kementerian Koperasi dan UKM Lembaga Pengelolaan Dana Bergulir Kementerian Koperasi dan UKM (LPDB-KUMKM) adalah unit kerja Kementerian Negara Koperasi dan UKM sebagai satuan kerja Pemerintah yang melaksanakan tugas operasional pelayanan publik di bidang keuangan melalui perusahaan Modal Ventura, pemberian pinjaman kepada KUKM tenant inkubator, pinjaman melalui KSP/USP Koperasi dan Pemberian pinjaman kepada KUKM strategis.
3. Pembiayaan Modal Ventura. Modal ventura adalah jenis pembiayaan dalam bentuk penyertaan modal pada suatu Perusahaan Pasangan Usaha (PPU), untuk jangka waktu tertentu (sementara).

4. Pembiayaan Program Kemitraan dan Bina Lingkungan (PKBL) BUMN PKBL adalah program untuk meningkatkan kemampuan usaha kecil agar menjadi tangguh dan mandiri melalui pemanfaatan dana dari bagian laba Badan Usaha Miliki Negara (BUMN). Dasar hukum PKBL adalah Peraturan Menteri Negara Badan Usaha Milik Negara Nomor Per-05/MBU/2007 tentang Program Kemitraan dan Program Bina Lingkungan BUMN (PKBL BUMN). ${ }^{7}$

\section{Hambatan dan Penyelesaian}

Dalam praktik kehidupan seharihari di masyarakat Indonesia, perjanjian jaminan fidusia sudah banyak digunakan dan senantiasa menunjukkan perkembangan. Pemuliaan jaminan fidusia ini dapat dilihat dari berbagai ketentuan yang mengatur dan memberikan perlindungan hukum bagi para pihak. UU Fidusia, Peraturan Pemerintah Nomor 86 Tahun 2000 tentang Tata Cara Pendaftaran Jaminan Fidusia dan Biaya Pembuatan Akta Jaminan Fidusia yang kemudian diubah menjadi Peraturan Pemerintah Nomor 21 Tahun 2015 tentang Tata Cara Pendaftaran Jaminan Fidusia dan Pembuatan Akta Jaminan Fidusia. 
Pemberian kredit kepada pelaku usaha UMKM tersebut bukanlah tanpa hambatan. Biasanya barang produksi yang bernilai adalah milik bersama. Selain itu barang jaminan juga mudah diperjualbelikan diantara mereka. Dalam kondisi demikian, jika lembaga jaminan fidusia yang dijadikan sebagai pilihan, maka diperlukan perlindungan hokum yang memadai bagi kreditur pada pelaksanaan kredit dengan jaminan fidusia. Kewenangan kreditur sebagai pemilik, ${ }^{8}$ dibatasi dengan kewajiban obligatoir, tetapi walaupun demikian kreditur tetap mempunyai kewenangan memiliki (kewenangan beschikking) atas benda miliknya. Kepemilikan tersebut terbatas, sampai sejauh diperlukan untuk melindungi kreditur.

Perlindungan hukum bagi kreditor dalam perjanjian jaminan fidusia ada yang bersifat preventif dan represif. Perlindungan yang diberikan oleh pemerintah untuk melindungi kreditor yang bersifat preventif menggunakan 2 sistem yaitu: sistem pendaftaran jaminan fidusia dan mengansuransikan objek jaminan. Pendaftaran jaminan fidusia memiliki 2 tujuan, yaitu:

1. Untuk memberikan kepastian hukum kepada pihak yang berkepentingan

2. Memberikan hak yang didahulukan (preferen) kepada penerima fidusia terhadap kreditur yang lain. Hal ini disebabkan jaminan fidusia memberikan hak kepada penerima fidusia untuk tetap menguasai bendanya yang menjadi objek jaminan fidusia berdasarkan kepercayaan. ${ }^{9}$

Sedangkan yang bersifat represif dengan pengaturan ancaman pidana bagi debitor yang mengalihkan atau mengadaikan objek jaminan fidusia bila tanpa seijin kreditor, larangan ini diatur dalam Pasal 36 UU Fidusia. Adapun berkaitan dengan pertanggung jawaban debitur dalam hal musnah atau dialihkan benda jaminan dalam perjanjian fidusia, berdasarkan UU Fidusia debitur tetap bertanggung jawab. Bentuk pertanggungjawaban itu adalah mengembalikan pinjaman kredit. Jika benda objek jaminan fidusia diasuransikan maka akan dilunasi oleh perusahaan asuransi di mana benda jaminan fidusia diasuransikan sesuai dengan isi perjanjian.

Apabila masih ada utang yang belum dibayar setelah dikurangi oleh uang dari klaim asuransi maka debitor wajib melunasinya. Jika benda jaminan fidusia tidak diasuransikan maka debitur bertanggung jawab penuh mengembalikan pinjaman kredit. Hal ini dikarenakan debitur telah terikat dalam perjanjian kredit dengan pihak kreditor, walaupun benda jamian fidusia musnah atau dialihkan.

Bagaimanakah dengan perlindungan hukum bagi debiturnya? Perlindungan

$8 \quad$ Kreditur yang menerima penyerahan hak milik, dalam fidusia, dengan penyerahan tersebut menjadi pemilik penuh atas benda jaminan, yang dalam batas-batas pengaturan diberikan kebebasan menikmati dan mengambil tindakan-tindakan atas benda jaminan tersebut.

$9 \quad$ H. Salim HS, Perkembangan Hukum Jaminan di Indonesia (PT Raja Grafindo Persada 2008 ) 82. 
kepada debitur diberikan dalam bentuk perikatan antara debitur dengan kreditur, hak debitur berupa hak tuntut pribadi (persoonlijkrech).

\section{PENUTUP}

Berdasakan paparan di atas, maka dapat disampaikan beberapa catatan sebagai berikut. Pertama, pelaku usaha UMKM merupakan potensi dari pelaksanaan kredit dengan jaminan fidusia. Kedua, dengan dibukanya peluang yang besar pemberian kredit dengan jaminan fidusia diharapkan mampu mendorong laju ekonomi negara. Ketiga, breeding atau pemuliaan lembaga jaminan fidusia dilakukan dengan dikeluarkannya pengaturan yang mengatur jaminan fidusia, dari tinggat UU sampai dengan peraturan pelaksananya.

\section{DAFTAR BACAAN}

H.S., Salim, Perkembangan Hukum Jaminan di Indonesia (PT RajaGrafindo Persada 2008).

Pramono, Nindyo, Sertifikasi saham PT Go Public dan Hukum Pasar Modal di Indonesia (disertasi, Universitas Gadjah Mada 1997).

Rajagukguk, Erman, 'Hukum Ekonomi Indonesia Memperkuat Persatuan Nasional, Mendorong dan Memperluas Kesejahteraan Sosial' (Seminar Pembangunan Hukum Nasional VII, Bali, 2003).
Satrio, J., Hukum Jaminan dan Hak Jaminan Kebendaan Fidusia (Citra Aditya Bakti 2002).

\section{Artikel}

Musnandar, Aries, 'Peran UKM dalam Pertumbuhan Ekonomi Bangsa' (2014) <http://www.umm.ac.id/id/ detail-32 1-peran-ukm-dalampertumbuhan-ekonomi-bangsaopini-umm.html> diakses 12 Maret 2015. 